\title{
SELING
}

Jurnal Program Studi PGRA

ISSN (Print): 2540-8801; ISSN (Online):2528-083X

Volume 5 Nomor 2 Juli 2019

P. 169-182

\section{URGENSI DIKLAT BERJENJANG TINGKAT DASAR PENDIDIK PADA PENINGKATAN KOMPETENSI GURU RAUDLATUL ATHFAL BEKERJASAMA DENGAN IGRA DAN HIMPAUDI KABUPATEN PASURUAN}

\section{Luluk Rochanah}

Sekolah Tinggi Ilmu Tarbiyah NU Al hikmah Mojokerto

lulukrochanah31@gmail.com

\begin{abstract}
Abstrak: This research aims a). Knowing the importance of basic level tiered education and training in the competence of Raudlatul Athfal educators in Pasuruan Regency b). Knowing how to apply tiered education at Basic Level RA Educators in Pasuruan c). Knowing the quality of educators in aligning behavioral attitudes after attending basic level tiered training. This study uses a qualitative approach that uses an approach based on a phenomenological perspective. The analysis was conducted with a phenomenological approach, observation and self-report. The collected data is identified based on the three components of Developmental Appropriateness Practices (DAP). This research concludes that the quality of teachers cannot be beaten by the education system in influencing the quality of education in other words, no matter how good the education system is, if not followed by good teacher quality, the quality cannot be maximally improved, basic level tiered education is one of coaching or improvement Educator competence, seen in the results of the Tiered Education and Training activities, namely (1) many Raudlatul Athfal teachers who do not understand the learning methods to be applied to teaching and learning activities of young children after attending a tiered education, the Raudlatul Athal teacher better understands the methods to be applied to the learning activities of children (2) basic level tiered education and training activities can add knowledge about early childhood knowledge (3) Raudlatul Athfal teacher can arrange management and learning tools perfectly from planning, implementation, observation to ev the teacher's aluasion can compile well (4) the material that has
\end{abstract}


been given in basic level tiered education and training is very suitable with the problems and needs experienced by the teacher of Raudlatul Athfal

Kata kunci : Basic Level Tiered Training, Teacher Competency Improvement.

\begin{tabular}{ccc} 
Submission & Revised & Publication \\
\hline 7 February 2019 & 13 March 2019 & 30 July 2019
\end{tabular}

\section{LATAR BELAKANG}

Pemberian layanan yang baik dan berkualitas pada era perkembangan saat ini semakin berpengaruh pada dunia pendidikan. Masyarakat semakin mengerti dan menyadari bahwa untuk dapat menghasilkan Output yang berkualitas tinggi bagi anak didik dan mampu mencapai perkembangan yang maksimal dapat diwujudkan jika semua tenaga pendidik, melaksanakan tugasnya secara optimal. Pemberian layanan anak didik yang baik untuk mencapai hasil yang maksimal dapat dilakukan jika didukung oleh sumber daya manusia yang memiliki kompetensi dan keahlian di dalam pendidikan. Kompetensi dan keahlian sangat berkaitan dengan profesionalisme. Maka dari itu tuntutan akan profesionalisme di pada pendidikan anak usia dini menjadi hal yang tidak dapat ditunda lagi, dan bahkan menjadi tuntutan untuk dilaksanakan. Pada pendidikan anak usia dini, tuntutan terhadap kemampuan memberikan layanan yang lebih profesional khususnya bagi pendidikan anak usia dini semakin memiliki arti penting bagi perkembangan anak.

Terkait dengan tuntutan kualitas dan profesionalisme guru. pemerintah telah menetapkan stándar yang wajid dipenuhi bagi pendidik, Pada pasal 26 PP Nomor 19 tahun 2005 tentang Stándar Nasional Pendidikan ditetapkan bahwa pendidik harus memiliki kualifikasi akademik dan kompetensi sebagai agen pembelajaran, sehat jasmani dan rohani, serta memiliki kemampuan untuk mewujudkan tujuan pendidikan nasional.

Undang - Undang Republik Indonesia no 20 tahun 2003 tentang sistem pendidikan nasional pasal 40 bahwa 1) Pendidik dan tenaga kependidikan berkewajiban menciptakan pendidikan yang bermakna, kreatif, dinamis, menyenangkan dan dialogis 2) Pendidik mempunyai komitmen secara professional untuk meningkatkan mutu pendidikan 3) memberikan teladan dan menjaga nama baik lembaga, profesi. Dan kepercayaan yang diberikan kepadanya.

Pendidik dituntut professional yang mana pendidik Anak usia dini harus meningkatkan kwalitas dan pengetahuan dan ketrampilan mengajar, bagi pendidik yang belum memiliki kualifikasi pendidikan S1 PAUD atau S1 Psikologi di harapkan mengikuti kegiatan pelatihan atau diklat berjenjang tingkat dasar untuk pendidik PAUD.

Profesionalisme tenaga pendidik adalah kemampuan seorang pendidik atau yang juga sering disebut sebagai guru, dalam melaksanakan tugas pokoknya mulai merencanakan hingga evaluasi pembelajaran. Indikator profesionalisme guru yaitu 
kompetensi guru, komitmen guru, dan pengembangan karier guru. Pada kompetensi guru, terdapat empat kompetensi yang harus dimiliki guru, meliputi: (1) kompetensi pedagogik; (2) kompetensi kepribadian; (3) kompetensi sosial; dan (4) kompetensi profesional. Upaya pencapaian visi dan misi lembaga tidak lepas dari peran sumber daya manusia yang ada di lembaga tersebut. Adapun salah satu kendala dalam upaya mencapaian visi dan misi lembaga yaitu kualifikasi tenaga pendidik yang bukan dari bidang yang dikerjakan.

Guna mengatasi persoalan tersebut perlu adanya kegiatan Pendidikan dan Pelatihan (diklat) untuk meningkatkan kualitas dan profesionalisme. Salah satu upaya dalam mengantisipasi permasalahan tersebut, Direktorat Pembinaan Pendidik dan Tenaga Kependidikan Anak Usia Dini (Dit.PPTK PAUDNI) Kemdikbud mengadakan program Diklat Berjenjang (Diklat Dasar, Diklat lanjutan, dan Diklat Mahir).

Diklat merupakan salah satu bentuk pengembangan pegawai yang pada akhirnya berdampak pada peningkatan kinerja pegawai. Pada sekolah atau lembaga pendidikan, fungsi diklat sangat penting untuk peningkatan kualitas tenaga pendidik di sekolah tersebut. Menurut Simamora (1997:34) "tujuan pelatihan dan pengembangan, antara lain: (a) memperbaiki kinerja; (b) membantu memecahkan persoalan operasional; (c) mempersiapkan pegawai untuk promosi serta memenuhi kebutuhan pribadi".

Untuk memahami undang-undang Republik Indonesia no 20 tahun 2003 tentang standar pendidikan nasional dan peraturan menteri pendidikan nomor 137 tahun 2014 tentang standar nasional pendidikan dan peraturan no 146 tentang kurikulum 2013 PAUD. Diperlukan pelatihan, diklat tentang kompetensi pendidik. Dengan Diklat diharapkan pendidik tidak melakukan kegiatan yang tidak sesuai dengan perkembangan anak.

Fakta yang terjadi dilapangan masih banyak dan Rendahnya kualitas dan kompetensi pendidik Raudlatul Athfal di Kabupaten Pasuruan para pendidik belum sepenuhnya memiliki ketrampilan mengajar dalam membuat perencanaan kegiatan bermain di lembaga masing - masing, pegalaman pendidik mengajar masih merujuk pada kegiatan turun temurun yang besumber dari senior, pendidik engan merubah kebiasaan sehari hari yang telah diterapkan oleh lembaga sejak lama walaupun perkembangan pembelajaran saat ini semakin pesat, secara tidak sadar bahwa pendidik memegang peran penting dalam proses perkembangan anak usia dini dari berbagai aspek, tugas pendidik diwajibkan menciptakan pembelajaran yang aktif dan kreatif.

\section{Diklat}

Menurut Atmodiwirio (2005, hlm. 36), yang dimaksud dengan pelatihan adalah: Bagian dari pendidikan yang mengaitkan proses belajar untuk meningkatkan keterampilan di luar sistem pendidikan yang berlaku dalam waktu yang relatif singkat dan metode yang lebih mengutamakan praktek dan teori. Menurut Hatton (1997, hlm. 118) diklat yang dilaksanakan harus berkaitan dengan pekerjaan yang 
akan dihadapi oleh pembelajar. Disebutkan bahwa: “... adults need to be equipped with skills appropriate for this clients...training programs are tailored to be concurrent with work, there by supporting the work-related needs of learners". Konsep ini menunjukkan bahwa pelatihan perlu dikaitkan dengan pemberian keterampilan yang tepat dan pekerjaan sesuai kebutuhan pembelajar sehingga program pelatihan perlu dibuat bersamaan dan didukung oleh kebutuhan pekerjaan yang akan dihadapi pembelajar. Sejalan dengan apa yang telah disampaikan Harris (2004), pada dasarnya pelatihan berbasis kompetensi memiliki karakteristik lain yaitu: (a) berdasarkan pada Standar Kompetensi; (b) isi dari pelatihan mengarah kepada kemampuan yang dibutuhkan untuk melakukan tugas tertentu; (c) pelatihan dapat berupa on-job, off-job, atau kombinasi keduanya; (d) adanya fleksibilitas waktu untuk mencapai suatu kompetensi; (e) adanya pengakuan terhadap kompetensi mutakhir/yang dimiliki saat ini; (f) pengujian berdasarkan kriteria tertentu; (g) pengujian dilakukan jika peserta pelatihan sudah siap, (h) menekankan pada kesanggupan untuk mentransfer pengetahuan dan ketrampilan pada situasi baru, (i) berfokus pada peserta pelatihan (perlu pendekatan individual/mandiri, kelompok dan klasikal), (j) materi pelatihan, penekanannya pada output dan outcome (hasil pelatihan), (k) penekanan pada apa yang haru dikerjakan,(l) penilaian kinerja berdasarkan kriteria unjuk kerja, (m) pencapaian kualifikasi kompetensi dapat melalui beberapa jalur. Untuk mencapai standar kompetensi yang telah ditetapkan oleh industri/ dunia usaha/asosiasi profesi, substansi

Menurut Santrock (2007: 266), pembelajaran (learning) adalah sebagai pengaruh permanen atas perilaku, pengetahuan, dan keterampilan berpikir, yang diperoleh melalui pengalaman. Ini berarti bahwa pengetahuan yang diperoleh peserta dalam kegiatan Diklat berjenjang tingkat dasar merupakan pengalaman yang akan membantu proses perubahan perilaku positif kerja peserta secara permanen setelah mengikuti Diklat berjenjang Tingkat Dasar. Salah satu faktor yang dipercaya mempengaruhi kualitas pendidikan adalah faktor kualitas guru. Bahkan secara tegas McKinsey \& Co (2007) menyatakan bahwa kualitas sistem pendidikan tidak dapat mengalahkan kualitas guru dalam mempengaruhi kualitas pendidikan. Dengan kata lain dapat dinyatakan bahwa sebaik apa-pun sistem pendidikan yang dibangun, namun jika tidak diikuti dengan kualitas guru yang baik, maka kualitas pendidikan tidak dapat diharapkan meningkat. Dari pendapat tersebut dapat dipahami bahwa peningkatan kualitas guru harus mendapatkan perhatian utama. Terdapat beberapa cara yang dapat digunakan untuk mendapatkan guru yang memiliki kualitas kompetensi yang baik, pembinaan bagi guru yang telah menjadi bagian dari suatu sistem di satuan pendidikan. Salah satu bentuk pembinaan atau peningkatan kompetensi yang dapat dilakukan adalah dengan diklat berjenjang tingkat dasar .

Diklat yang dilaksanakan kerjasama antara Himpaudi dan IGRA Kabupaten Pasuruan. Bertujuan memperdalam pengetahuan, memantapkan sikap meningkatkan ketrampilan pendidik anak usia dini untuk membawa kemajuan dan mencapai keberhasilan sesuai apa yang diharapkan oleh masyarakat yaitu ouput anak didik yang berkualitas. Untuk itu agar dapat membantu meningkatkan kualitas guru Raudlatul athfal salah satu nya adalah dengan Diklat Berjenjang Tingkat Dasar, 172 | Volume 5, Nomor 1, Januari 2019 || SELING: Jurnal Program Studi PGRA 
diklat ini berkolaborasi antara IGRA Kabupaten Pasuruan, HIMPAUDI dan STITNU Alhikmah Mojokerto.

\section{Kompetensi pendidik}

Terkait dengan kompetensi, McShane \& Glinow (2008, hlm. 36) menjelaskan bahwa kompetensi adalah keterampilan, pengetahuan, bakat, nilai-nilai, pengarah, dan karakteristik pribadi lainnya yang mendorong ke arah performansi unggul. Gilley \& Enggland (2008, hlm. 36) membahas kompetensi dari aspek pengembangan sumber daya manusia, bahwa kompetensi adalah kemampuan yang dimiliki seseorang sehingga membolehkan ia untuk mengisi suatu peran. Kompetensi juga merupakan pengetahuan dan keterampilan yang menjadi kunci untuk menghasilkan output dari suatu pelatihan dan pengembangan peran mereka. Sebagaimana yang telah dikemukan oleh beberapa ahli di atas, penulis berkesimpulan bahwa yang dimaksud dengan pendidikan dan pelatihan berbasis kompetensi adalah keseluruhan kegiatan untuk memberikan atau meningkatkan serta mengembangkan pengetahuan, keterampilan dan perubahan perilaku dalam mengembangkan bakat seseorang sehingga dapat melakukan pekerjaan sesuai dengan yang dipersyaratkan.

\section{METODE PENELITIAN}

Jenis Penelitian ini adalah penelitian kualitatif dengan menggunakan strategi studi kasus. Menurut pengamat bahwa "studi kasus", tendensi sentral dari semua jenis studi kasus, adalah mencoba menjelaskan keputusan-keputusan tentang mengapa studi kasus tersebut dipilih, bagaimana mengimplementasikannya, dan apa hasilnya.

\section{a. Pendekatan Penelitian}

Dalam metode penelitiannya menggunakan pendekatan penelitian kualitatif fenomenologis untuk mengembangkan pemahaman. Alasan memilih menggunakan metode tersebut yaitu karena pendekatan kualitatif menerjemahkan pandanganpandangan dasar interpretif dan fenomenologis, beberapa pandangan mendasar tersebut menurut Sarantakos (Poerwandari, 1998) menyatakan bahwa (1) realitas sosial adalah sesuatu yang subjektif dan diinterpretasikan, bukan sesuatu yang berada di luar individu-individu, (2) manusia tidak secara sederhana mengikuti hukum-hukum alam di luar diri, melainkan menciptakan rangkaian makna dalam menjalani kehidupannya, (3) ilmu didasarkan pada pengetahuan sehari-hari, bersifat induktif, idio grafis dan tidak bebas nilai, (4) penelitian bertujuan untuk memahami kehidupan sosial.

\section{b. Teknik Analisa Data}

1). Metode Observasi

Untuk memperoleh data yang obyektif, dilakukan obervasi langsung kelokasi penelitian pada saat kegiatan peyelenggaraan pendidikan dilaksanakan agar mudah mendapatkan data yang akurat, secara langsung tanpa dipengaruhi oleh factor internal maupun eksternal lainnya. Hasil observasi mengenahi keadaan yang teradi dilapangan dimana kegiatan program pembelajaran dilaksanakan. Dalam penelitian ini, peneliti melakukan observasi terhadap kompetensi kepala sekolah, guru, dan 
instansi yang terkait. Observasi terhadap guru meliputi kompetensi guru yang berkaitan dengan diklat berjenjang tingkat dasar dikembangkan di sekolah. Observasi terhadap guru meliputi aktifitas guru bagaimana aktifitas guru dalam kegiatan pembelajaran baik didalam dan di luar kelas. Pemanfaatan teknologi informasi menjadi ujung tombak kegiatan observasi yang dilaksanakan seperti pemanfaatan tape recorder dan handy camera. Hal ini sesuai dengan pendapat Spradley(dalam Prastowo, 2012:44) menyebutkan bahwa dalam setiap situasi sosial ada 3 komponen yang diamati, yakni ruang (tempat), pelaku (aktor) dan kegiatan (aktivitas). Dalam hal ini lokasi adalah RA di Kabupaten Pasuruan pada peningkatan kompetensi guru Raudlatul Athfal.

2). Metode Wawancara

Wawancara dilakukan secara langsung dengan key informan seperti kepala sekolah, wali murid, ketua IGRA kecamatan, guru - guru Raudlatul Athfal. Kabupaten Pasuruan yang anaknya berusia 2-6 tahun. Wawancara ini untuk mengetahui sejauh mana urgensi diklat berjenjang tingkat dasar pendidik pada peningkatan kompetensi guru RA di Kabupaten Pasuruan yang di implementasi pada lembaga.

3).Metode Dokumentasi

Penelitian ini menggunakan metode dokumentasi untuk mendapatkan sejauh mana urgensi diklat berjenjang tingkat dasar pendidik pada peningkatan kompetensi guru di Raudlatul Athfal Kabupaten Pasuruan. Fungsi data yang berasal dari pre tes, pos tes, dokumentasi program tahunan, program semester, program mingguan dan program harian sebagai data pelengkap bagi data primer yang diperoleh melalui observasi dan wawancara.

Pada penelitian ini, peneliti menggunakan metode dokumentasi untuk mendapatkan seberapa jauh urgensi diklat berjenjang tingkat dasar pendidik pada peningkatan kompetensi guru di Raudlatul Athfal Kabupaten Pasuruan, data yang berasal dari dokumentasi program tahunan, program semester, program mingguan dan program harian sebagai data pelengkap bagi data primer yang diperoleh melalui observasi dan wawancara.

\section{c. Pengecekan Keabsahan Data}

Menurut Moloeng (2012:330), trianggulasi adalah teknik pemeriksaan keabsahan data yang memanfaatkan sesuatu yang lain, di luar data untuk keperluan pengecekan atau sebagai pembanding terhadap data itu. Teknik trianggulasi yang paling banyak digunakan adalah pemeriksaan melalui sumber lainnya. Denzin (dalam Moloeng, 2012:330) membedakan empat macam trianggulasi sebagai teknik pemeriksaan yang memanfaatkan penggunaan sumber, metode, penyidik dan teori.

\section{HASIL DAN PEMBAHASAN}

\section{Gambaran Umum Raudlatul Athfal Kabupaten Pasuruan}

RA (Raudlatul Athfal) Di wilayah Kabupaten Pasuruan Letak lokasi rata-rata di daerah pesisir pantai 0-25 dpl, antara lain Beji, Bangil, Pohjentrek, Gondang wetan, Winongan, Lekok, Nguling, adapun wilayah didataran sedang 25 - $100 \mathrm{dpl}$ antara lain : Rembang, Grati, gempol sedangkan yang terletak didataran 100-500 dpl adalah 174 | Volume 5, Nomor 1, Januari 2019 || SELING: Jurnal Program Studi PGRA 
Sukorejo, Pandaan, Prigen $>1000$ dpl. Pada Wilayah Pesisir mayoritas yang mendiami etnis Jawa Madura.

Adapun tujuan RA (Raudlatul Athfal) Mempersiapkan generasi muslim yang Cerdas, Disiplin, Mandiri dan Berakhlakkul karimah. Melatih kemandirian dan sikap sosial pada anak agar bisa menghormati yang lebih tua dan menyayangi sesamanya, Mengembangkan kemampuan bakat dan minat anak sejak dini, Menata lingkungan sekitar agar sehat, bersih, rapih dan indah, Menumbuh kembangkan semangat belajar dan disiplin, Melaksanakan pembelajaran aktif, kreatif, efektif dan menyenangkan, Menanamkan gemar ibadah sejak dini, Melatih anak bertanggung jawab di sekolah dan di rumah, Menumbuh kembangkan sikap perilaku dan amaliyah yang berdasarkan agama islam,belajar dengan Ceria, Berakhlak Mulia, Menanamkan pendidikan agama sejak dini, Membiasakan membaca dan memahami Al-Qur'an, Melatih dan membiasakan beribadah, Menanamkan dan melatih kemampuan dasar calistung, Menciptakan kegiatan yang dapat memberi kesempatan murid berekspresi, Membantu peserta didik menyiapkan diri pada pendidikan yang lebih tinggi.

Hasil dari kegiatan diklat berjenjang tingkat dasar adalah merupakan tujuan Raudlatul Athfal sesungguhnya guru merasa mendapatkan ilmu yang bermanfaat antara lain peningkatan kegiatan pembelajaran yang menyenangkan melalui kegiatan bermain, bagaimana cara terbaik pada pengasuhan anak didik, pengetahuan tantag pemakaian APE, pemahan guru tentang holistic integrative, bagaimana penyusunan kurikulum sesuai kurikulum 2013, Etika pendidik, sikap dan perilaku pendidik layanan kesehatan, pengelolan pembelajaran, bagaimana cara peningkatan sarana prasarana serta peningkatan pembinaan terhadap guru. Materi materi ini belum pernah didapatkan oleh guru-guru Raudlatul Athfal di Kabupaten Pasuruan maka dari itu guru sangat antusias dalam mengikuti materi diklat berjenjang tingkat dasar ini. Hal ini mendorong guru untuk tidak beranjak dari kursi karena materi sangat menarik. Tercapainya kualitas dan kompetensi guru Raudlatul Athfal sangat menyenangkan guru tidak lepas dari minat dan semangat guru itu sendiri untuk belajar menambah wawasan dan ilmu pengetahuan.

\section{Konsep Program Pendidikan dan Latihan Dasar}

Proses kegiatan Diklat Berjenjang tingkat dasar memiliki konsep yang telah di tetapkan yaitu melalui 4 tahapan, tahap pertama : tahap persiapan kegiatan Diklat Ittihad, Manajemen Diklat Berjenjang Tingkat Dasar Untuk Meningkatkan Kompetensi Guru Paud, tahap kedua : tahap pelaksanaan kegiatan Diklat Berjenjang, tahap ketiga : tahap pasca Diklat Berjenjang yaitu pembuatan tugas mandiri, tahap ke empat tahap kelulusan. Konsep program diklat berjenjang tingkat dasar ini ditujukan untuk mempersiapkan pendidik benar benar sebagai pengasuh Raudlatul Athfal yang berkualitas dan memiliki berkompetensi yang baik.

Narasumber mampu memotivasi dan mendorong peserta selama kegiatan berlangsung narasumber dapat membawa peserta kearah tujuan materi yang disajikan hingga perserta paham akan materi yang disajikan membuat peserta tidak bosan dan tidak jenuh,bila peserta kelihatan lelah pemateri memberikan ice breaking yang berkaitan dengan materi pembelajaran PAUD, namun beberapa instruktur/narasumber terlalu teoritis dan tidak memberikan contoh, konkrit pada 
materinya,Hal ini menyebabkan sebagian peserta sulit memahami materi yang telah di berikan. Jadwal pemberian Materi diklat ditambah karena guru haus akan materi materi yang belum pernah didapat baik di organisasi maupun dari dinas setempat.

Peserta rata rata menilai materi bahan ajar sangat penting, dan beberapa peserta menilai ada beberapa prioritas materi ajar yang terkait langsung dengan tugas utama sebagai guru PAUD seperti materi perencanaan, metode/media, dan evaluasi pembelajaran di tambah dan kuatkan lagi karena materi ini sangat penting untuk di implementasikan pada lembaga saat sedang melangsungkan kegiatan pembelajaran.

Dengan kegiatan diklat berjenjang tingkat dasar para guru Raudlatul athfal dapat memperdalam pengetahuan, memantapkan sikap dan meningkatkan ketrampilan pendidik Raudlatul Athfal untuk membawa kemajuan memperoleh keberhasilan. Memberikan contoh arahan kepada orang tua dan keluarga tentang cara pemberian rangsangan pendidikan kepada anak untuk dilanjutkan dirumah.

\section{Dampak diklat berjenjang tingkat dasar}

Berdasar pengamatan kemajuan peningkatan kualitas dan jumlah hasil karya peserta diklat berjenjang tingkat dasar masih 75\% terlaksana. Peningkatan kwalitas terlihat pada kegiatan pembuatan media pembelajaran berdasar tema pembelajaran yang ada pada PAUD. Peserta terlihat sudah dapat menekan atau efisiensi biaya dalam membuat media media pembelajaran terlihat dari pemakaian bahan-bahan bekas dan bahan alam yang ada disekitar lingkungan peserta hal ini adalah merupakan suatu bukti peningkatan kreativitas peserta Diklat berjenjang tingkat dasar PAUD. Hasil yang maksimal terlihat dari Diklat Dasar ini adalah meningkatnya kualitas komunikasi dan pengatahuan dengan seluruh stakeholder sekolah seperti murid, guru, Kepala Sekolah,orang tua dan penjaga sekolah, yang bertujuan membangun kerjasama dalam pendidikan dasar yang berkualitas tinggi bagi kebupaten Pasuruan dan berkontribusi langsung terhadap SDM guru Raudlatul Athfal.

Dalam pelaksanaan tugasnya sebagai pendidik PAUD di lembaganya masingmasing. Pembelajaran (learning) berpengaruh atas perilaku, pengetahuan, dan keterampilan berpikir, yang diperoleh melalui pengalaman. Hal ini dapat diartikan bahwa pengetahuan yang didapat peserta dalam kegiatan Diklat berjenjang tingkat dasar adalah pengalaman yang sangat menyenangkan proses perubahan kegiatan yang positif kerja peserta secara maksimal setelah mengikuti Diklat berjenjang Tingkat Dasar.

Perubahan perilaku positif pada kegiatan pebelajaran peserta terkait dengan aspek Hasil/Result berpengaruh pada lembaga kerja peserta Diklat yaitu peningkatan efektivitas dan efisiensi yang diperlihatkan pada bentuk jumlah dan kualitas hasil karya untuk kegiatan pembelajaran. Meningkatnya kegiatan pembelajaran dan pelayanan serta peningkatan komunikasi antar personal terhadap peserta didik dan lingkungan lembaga kerja pasca Diklat berjenjang tingkat dasar.

Diklat berjenjang tingkat dasar sangat bermanfaat pada peningkatan Profesionalisme Guru PAUD, Profesionalisme guru dituntut agar terus berkembang sesuai dengan perkembangan ilmu pengetahuan, teknologi dan kebutuhan 176 | Volume 5, Nomor 1, Januari 2019 || SELING: Jurnal Program Studi PGRA 
masyarakat, termasuk kebutuhan terhadap sumber daya manusia yang berkualitas dan memiliki kemampuan untuk mampu bersaing baik dalam forum regional, nasional maupun internasional. Guru Raudlatul athfal adalah salah satu bidang pekerjaan yang terkait langsung dengan kebutuhan masyarakat. Maka dari itu jika masyarakat semakin kritis mengamati dan menilai keberhasilan dan kegagalan tugas guru itu wajar. Guru merupakan 'the front linear"nya berbagai upaya peningkatan mutu pendidikan nasional (Sa'ud, 2000:35). Demikian pula guru merupakan salah satu faktor penentu keberhasilan atau kegagalan upaya-upaya peningkatan mutu dan inovasi pendidikan di tingkat sekolah (Fullan, 1992; Goodlad, 1990). Para orang tua sangat mengharapkan layanan pendidikan yang baik dan berkualitas, dan sebagian besar para orangtua meletakkan tanggung jawab terdepan untuk mewujudkan harapan perkembangan anak yang maksimal berada di pundak guru, Dari kesimpulan diatas peran guru tidak bisa digantikan oleh yang lain. Dipandang dari dimensi pembelajaran, peran guru Raudlatul Athfal tetap dominan walaupun saat ini pengaruh teknologi yang sudah merakyat namun namun peran guru sangat penting dalam proses kegiatan pembelajaran, oleh karena guru Raudlatul Athfal merasa kegiatan diklat berjenjang tingkat dasar sangat bermanfaat pada peningkatan kualitas dan mutu pendidikan anak usia dini khususnya pada lembaga Raudlatul Athfal.

\section{Diskusi Data/Temuan Penelitian}

Untuk selanjutnya hasil penelitian akan dikaitkan dengan teori atau hasil penelitian yang relevan. Tujuan mengaitkan dengan teori atau hasil penelitian yang relevan adalah untuk mempermudah penarikan kesimpulan.

Peningkatan kualitas guru Raudlatul Athfal harus mendapatkan perhatian utama yaitu dengan beberapa cara yang terbaik pembianaan guru Raudlatul athfal yang telah menjadi bagian dari sistem pendidikan nasional salah satu pembinaannya dengan melalui cara diklat berjenjang tingkat dasar. Berdasarkan hasil analisis secara umum penyelenggaraan Diklat Berjenjang Tingkat Dasar ini dalam kategori Baik. Secara khusus hasil penelitian ini dapat dijelaskan berdasarkan peningkatan kualitas dan jumlah hasil karya peserta diklat berjenjang tingkat dasar sudah Nampak pada Peningkatan pembuatan media yang bervariasi dan lagu sudah berdasarkan tema pembelajaran yang telah ditetapkan pada lembaga. Peningkatan efisiensi biaya peserta pasca diklat pada kegiatan media dengan menggunakan bahan-bahan bekas dan bahan alam di sekitar lingkungan terdekat, meningkatnya kualitas komunikasi dengan seluruh stakeholder sekolah seperti murid, guru, Kepala Sekolah,orang tua dan penjaga sekolah, terlihatnya kasih sayang perlindungan kesehatan asuhan kasih sayang dan rangsangan pendidikan telah di terapkan sesuai dengan tahap perkembangan dan kemampuan anak didik. Hal ini seiring seuai dengan pendapat Santrock (2007: 266), pembelajaran (learning) adalah sebagai pengaruh permanen atas perilaku, pengetahuan, dan keterampilan berpikir, yang diperoleh melalui pengalaman.

Hasil pembelajaran peserta yang di terapkan pada lembaga pasca mengikuti diklat benjenjang tingkat dasar dilihat dari perubahan perilaku peserta setelah mengikuti Diklat dalam pelaksanaan tugasnya sebagai pendidik PAUD di lembaganya masing-masing. Ini berarti bahwa pengetahuan yang diperoleh peserta dalam Volume 5, Nomor 2, Juli 2019 || SELING: Jurnal Program Studi PGRA | 177 
kegiatan Diklat merupakan pengalaman yang akan membantu proses perubahan perilaku positif kerja peserta secara permanen setelah mengikuti Diklat Tingkat Dasar. Materi yang didapat pada diklat berjenjang tingkat dasar adalah Perubahan perilaku positif kerja peserta terkait dengan aspek Hasil yang berdampak terhadap lembaga kerja peserta Diklat yaitu peningkatan efektivitas dan efisiensi yang ditunjukkan dalam bentuk jumlah dan kualitas hasil karya, peningkatan pelayanan serta peningkatan komunikasi interpersonal peserta terhadap peserta didik dan lingkungan lembaga kerja pasca Diklat.

Meningkatkan profesionalisme guru Raudlatul Athfal setelah mengikuti proses diklat berjenjang tingkat dasar. Dalam pemahaman dan keterampilan Tenaga Pendidik/ Pengasuh dibidang pembelajaran yang tepat untuk anak usia dini, Guru Raudlatul Athfal telah mampu menerapkan dan mentransfer serta mengembangkan pengetahuan dan ketrampilan yang telah diperoleh saat mengikuti diklat berjenjang tingkat dasar antara lain : a) Kebijakan Program PAUD b) Perkembangan Anak 0-6 Tahun c) Konsep Dasar PAUD d) Etika dan karakter pendidik PAUD e) Komunikasi dan pengasuhan f) Cara belajar anak usia dini g) Perencanaan pembelajaran $h$ ) Pengenalan ABK i) kesehatan gizi.

Hal ini sejalan dengan pendapat Hatton (1997, hlm. 118) diklat yang dilaksanakan harus berkaitan dengan pekerjaan yang akan dihadapi oleh pembelajar. Disebutkan bahwa: "... adults need to be equipped with skills appropriate for this clients...training programs are tailored to be concurrent with work, there by supporting the work-related needs of learners". Konsep ini menunjukkan bahwa pelatihan perlu dikaitkan dengan pemberian keterampilan yang tepat dan pekerjaan sesuai kebutuhan pembelajar sehingga program pelatihan perlu dibuat bersamaan dan didukung oleh kebutuhan pekerjaan yang akan dihadapi pembelajar. Sejalan dengan apa yang telah disampaikan Harris (2004), pada dasarnya pelatihan berbasis kompetensi memiliki karakteristik lain yaitu: (a) berdasarkan pada Standar Kompetensi; (b) isi dari pelatihan mengarah kepada kemampuan yang dibutuhkan untuk melakukan tugas tertentu; (c) pelatihan dapat berupa on-job, off-job, atau kombinasi keduanya; (d) adanya fleksibilitas waktu untuk mencapai suatu kompetensi; (e) adanya pengakuan terhadap kompetensi mutakhir/yang dimiliki saat ini; (f) pengujian berdasarkan kriteria tertentu; (g) pengujian dilakukan jika peserta pelatihan sudah siap, (h) menekankan pada kesanggupan untuk mentransfer pengetahuan dan ketrampilan pada situasi baru, (i) berfokus pada peserta pelatihan (perlu pendekatan individual/mandiri, kelompok dan klasikal), (j) materi pelatihan, penekanannya pada output dan outcome (hasil pelatihan), (k) penekanan pada apa yang haru dikerjakan,(l) penilaian kinerja berdasarkan kriteria unjuk kerja, (m) pencapaian kualifikasi kompetensi dapat melalui beberapa jalur. Untuk mencapai standar kompetensi yang telah ditetapkan oleh industri/ dunia usaha/asosiasi profesi, substansi.

Hal ini berarti bahwa pengetahuan yang diperoleh peserta dalam kegiatan Diklat berjenjang tingkat dasar merupakan pengalaman yang dapat membantu proses perubahan perilaku positif kerja peserta secara permanen setelah mengikuti Diklat berjenjang Tingkat Dasar.

178 | Volume 5, Nomor 1, Januari 2019 || SELING: Jurnal Program Studi PGRA 
1. Implementasi pendidik setelah mengikuti diklat berjenjang pada lembaga Implementasi Diklat berjenjang tingkat dasar terhadap kualitas dan Kompetensi pendidik Raudlatul Athfal di kabupaten Pasuruan tidak lepas dari peran kepala sekolah sebagai manajer, guru sebagai pendidik dan orang tua.

Bekerja dengan kondisi dan situasi apapun dengan hati yang gembira dan bahagia penuh canda dan tawa berkaitan dengan komptensi pendidik kesiapan Guru akan materi yang akan diajarkan pada Lingkungan kerja yang menyenangkan penting dalam sebuah lembaga Pendidikan karena dapat membuat pendidik lebih antusias, dan bahagia pada saat bekerja dalam membimbing anak didik hal ini sangat berkaitan juga pada seorang pendidik terhadap pembelajaran dan perkembangan anak didik. Karena pendidik yang telah mengikuti diklat berjenjang tingkat dasar seluruh usaha, cara, teknik, dan metode untuk mendorong para guru untuk ikhlas bekerja sebaik mungkin. Setelah mengikuti diklat berjenjang tingkat dasar Terbukti dengan adanya komunikasi penyelenggara dengan proses pelaksanaan, kesiapan guru dalam proses pembelajaran, metode dan teknik mengajar guru dapat memberikan semangat dan motivasi anak didik dalam mengikuti pembelajaran yang telah terkonsep sesuai dengan standar kompetensi guru PAUD.

Pengetahuan tentang anak usia dini mengalami peningkatan yang membangakan, namun hal ini tidak berhenti pada taraf diklat saja pengimplementasian pada lembaga perlu Penerapkan ilmu yang telah didapat saat mengikuti diklat berjenjang tingkat dasar Karena materi pelatihan tidak hanya teori namun materi bagaimana kita dapat menerapkan dan melaksanakan pendekatan terhadap anak, pembuatan lagu- lagu baru sesuai dengan tema belajar, meningkatkan perilaku pendidik dan kualitas pendidikan pada pendidik Raudlatul Athfal, dan mampu memberikan pelayanan tumbuh kembang anak usia dini secara maksimal pun juga dapat mempraktekkan materi yang telah diperoleh.

Pendidik yang telah mengikuti diklat berjenjang memiliki perilaku ini mempunyai empat aspek, perencanaan, pembelajaran, Pelaksanaan pengajaran, evaluasi pembelajaran, komunikasi pengasuhan. Beberapa peserta merasa mengalami kesulitan Peserta sulit merubah format perencanaan pembelajaran karena masing-masing lembaga telah memiliki format dan program perencanaan pembelajaran (model sendiri) dan telah menyusun program pada lembaga . sebelum peserta mengikuti Diklat, Peserta lebih tertarik dengan materi ice breaking, lagu baru namun setelah mengikuti diklat peserta terarik pada hal- hal yang berkaitan dengan anak didik. Peningkatan sikap positif oleh peserta terhadap anak usia dini meningkat seperti cara peserta berkomunikasi dengan anak didik dan orang-orang yang ada di sekitar lingkungannya. Komunikasi peserta dalam pengasuhan, peserta mengalami peningkatan dalam berinteraksi dan berkomunikasi dengan anak didik, diskusi dengan teman sejawat. Peserta telah memahami bahwa setiap anak tidaklah sama, sehingga pendekatan dalam berinteraksi dan berkomunikasi juga berbeda.

2. Implementasi Pendidik terhadap perkembangan anak didik

Implementasi pendidik terhadap Perkembangan dan perilaku anak, perilaku anak tidak terlepas dari peran guru yang memiliki kompetensi. Kepala sekolah, guru 
yang berkompeten, memegang peranan penting dalam implementasi menumbuhkan perkembangan anak.

Peran guru setelah mengikuti diklat berjenjang tingkat dasar, Hasil penelitian menunjukkan peranan guru yang telah mengikuti diklat dalam mengimplementasikan perkembangan anak anak telah ditunjukkan dengan baik. (1) pemberian keteladanan (2) evaluasi (3) penyelenggaraan kegiatan-kegiatan (4) komitmen menjalankan tugas. Hal tersebut mendorong untuk adanya keberanian konsekuensi dari perubahan yang dilakukan. Oleh sebab itu guru memulai perubahan tersebut dari dalam dirinya sendiri. Hal ini agar dapat diikuti oleh seluruh warga sekolah. Interaksi guru dengan anak sangat bergantung oleh sikap guru terhadap anak didik di sekolah. Hasil penelitian menunjukkan bahwa guru mampu menjalankan perannya dengan baik. Guru tidak hanya berfungsi sebagai pengajar tetapi juga sebagai pendidik sehingga memiliki kewajiban terhadap pengembangan anak baik secara kognitif, afektif dan psikomotorik. Peranan guru dengan lingkungan yang menyenangkan sangat berpengaruh pada perkembangan kognitif, afektif dan psikomotorik anak. Pada pertumbuhan dan perkembangan anak adalah menjadi tanggung jawab bersama, guru sebagai orang tua di sekolah juga memperhatikan bagaimana agar pertumbuhan dan perkembangan anak dapat berkembang secara optimal. Guru juga berinteraksi dengan anak berperan sebagai teman bagi anak, anak dapat bercerita kepada guru tentang masalah-masalah kecil yang dihadapi anak sehingga terwujudnya keakraban antara guru dan anak. Hurlock ( 1978 : 336 ) mengemukakan bahwa hubungan antara anak (siswa) dengan guru di tentukan oleh sikap guru terhadap anak dan sikap anak terhadap gurunya. Sikap ini bergantung pada bagaimana guru dan anak mempersepsi satu sma lain.

\section{KESIMPULAN}

Kualitas guru tidak dapat dikalahkan oleh sitem pendidikan dalam mempengaruhi kualitas pendidikan dengan kata lain sebaik apapun sistem pendidikan jika tidak di ikuti dengan kualitas guru yang baik maka kualitas tidak dapat meningkat dengan maksimal, dengan dilakukan diklat berjenjang tingkat dasar yang merupakan salah satu pembinaan atau peningkatan kompetensi pendidikyang mana hal ini terlihat pada hasil dari kegiatan Diklat Berjenjang yaitu (1) banyak guru Raudlatul Athfal yang belum memahami metode pembelajaran untuk diterapkan pada kegiatan belajar mengajar anak usia dini setelah mengikuti diklat berjenjang, guru Raudlatul Athal lebih memahami metode untuk diterapkan pada kegiatan pembelajaran anak usia dini (2) kegiatan diklat berjenjang tingkat dasar dapat menambah wawasan ilmu pengetahuan tentang anak usia dini (3) Guru Raudlatul Athfal dapat menyusun manajemen dan perangkat pembelajaran dengan sempurna mulai dari kegiatan perencanaan, pelaksanaan, pengamatan hingga evaluasi guru dapat menyusun dengan baik (4) materi yang telah di berikan pada diklat berjenjang tingkat dasar sangat sesuai dengan permasalahan dan kebutuhan yang di alamai oleh guru Raudlatul Athfal 


\section{DAFTAR PUSTAKA}

Akademik dan Kompetensi Guru. Kementerian pendidikan dan kebudayaan Republik Indonesia direktorat jenderal PAUD (online). www.paudni.kemdikbud.go.id)

Akuntono, Indra.2012. Rata rata Hasil Uji Kompetensi guru Masih Rendah. http://edukasi.kompas.com/ read/2012/03/ 16/ 17455390/ Di unduh 25 April 2018

Azwar, Syaifudin. 2000. Metode Penelitian. Yogyakarta: Putra Pelajar

Direktorat PTK PAUDNI petunjuk teknis diklat berjenjang,jakarta: PTK PAUDNI, 2011

Eva Riza, 2014. Efektifitas diklat berjenjang tingkat dasar pendidik dan tenaga kependidikan PAUD, Jurnal Pendidikan AUD PPS UNJ volume 8 edisi 1. April 2014

https://anzdoc.com/efektivitas-diklat-berjenjangtingkat-dasar-pendidik-dantena.html

Furjanic, Sheila W \& Laurie A Trotman.2000.Turning Training into Learning. New York : AMACOM

Herawan, Endang dan Nani Hartini. Manajemen Tenaga Pendidik dan Kependidikan. Dalam Tim Dosen Administrasi Pendidikan Universitas Pendidikan Indonesia. 2014.

Indarti, Sri dan Rispantyo. 2009. Pengaruh Pendidikan Pelatihan, Motivasi Kerja dan Lingkungan Kerja Terhadap Kinerja Guru Sekolah Dasar. Jurnal Manajemen Sumberdaya Manusia. Volume 3 No. 2 Desember 2009

Ittihad, 2016. Managemen Diksar untuk meningkatkan kompetensi guru PAUD (kegiatan bekerjasama dengan SKB dan HIMPAUDI kec. Aikmel, https://media.neliti.com/media/publications/223774-manajemen-diklatberjenjang-tingkat-dasa.pdf

Kementrian Pendidikan dan kebudayaan direktorat jendral pendidikan anak usia dini dan pendidikan masyarakat, 2016. Bahan kebijakan pembinaan PAUD

Lexy J.Moleong. (2002) Metodologi Penelitian Kualitatif,Bandung: Remaja Rosdakarya

Mirza, Munawar S., Asghar Ali. 2014. Effectiveness of Training Program in Changing

Mulyasa, E. (2007). Menjadi Guru Profesional Menciptakan Pembelajaran Kreatif dan Menyenangkan. Bandung: Rosdakarya. Mc.David, James C., dan Laura R. L.

Hawtorn.Program Evaluation \&Performance Measurement: An

Introductionto Practice. California: Sage PublicationInc, 2006.

Teachers' Attitude towards Students' Corporal Punishment. Journal of Research And Reflections in EducationVol.8, No.2, pp 97-104.Tersedia dalam ttp://www.ue.edu.pk/jrre

Peraturan Menteri Pendidikan dan kebudayaan Republik Indonesia nomor 137 tahun 2014 tentang standar pendidikan anak usia dini 
Peraturan Menteri Pendidikan dan kebudayaan Republik Indonesia nomor 146 tahun 2014 tentang kurikulum 2013 pendidikan anak usia dini

Poerwandari, E. Kristi. 1998. Pendekatan Kualitatif Dalam Penelitian Psikologi. Jakarta: LPSP3-UI

Robert K.Yin, 1977. Studi Kasus: desain dan metode, penterjemah Djauzi Mundzakir (Jakarta:PT Raja Grafindo persada

Sujiono, Yuliani Nurani, 2009. Konsep dasar pendidikan anak usia dini. Jakarta. Indeks

Robert K.yin studi Kasus : desain dan metode, penterjemah Djauzi Munzakir ( jakarta PT Raja Grafindo persada, 1997) h 17 